\title{
PENGARUH DIMENSI KUALITAS TERHADAP KEPUASAN PELANGGAN DUNIA FANTASI PT. PJA
}

\author{
Lithrone Laricha Salomon, M. Agung Saryatmo dan Stephanie Meliana \\ Program Studi Teknik Industri Universitas Tarumanagara \\ e-mail: laricha_salomon@yahoo.com
}

\begin{abstract}
ABSTRAK
Dunia Fantasi PT. PJA merupakan pusat hiburan outdoor terbesar di Indonesia. Sebagai pusat hiburan terbesar, Dunia Fantasi harus memberikan pelayanan yang terbaik bagi pengunjung. Data yang dianalisa diambil dari tujuh dimensi pariwisata, yaitu : dimensi atraksi dan hiburan, fasilitas, pelayanan, transportasi dan infrastruktur, informasi dan promosi, harga dan jaminan keamanan. Berdasarkan perhitungan model SERVQUAL, ketujuh dimensi tersebut masih bernilai negatif sehingga pelayanan di Dunia Fantasi masih perlu ditingkatkan. Usulan perbaikan untuk ketujuh dimensi tersebut akan dibuat dengan menggunakan metode QFD.
\end{abstract}

Kata kunci: Dunia Fantasi, SERVQUAL, dimensi pariwisata, QFD

ABSTRACT

Dunia Fantasi PT. PJA is the largest outdoor entertainment center in Indonesia. As the largest entertainment center, Dunia Fantasi should provide the best service for visitors. The data analyzed were taken from the seven dimensions of tourism, those are the dimensions of attractions and entertainment, facilities, services, transportation and infrastructure, information and promotion, price and security assurance. Based on the SERVQUAL model calculations, the seventh dimension is negative so that the service is still needs to be improved in Dunia Fantasi. Proposed improvements to the seventh dimension will be created using the QFD method.

Keywords: Dunia Fantasi, SERVQUAL, dimension of tourism, QFD

\section{PENDAHULUAN}

Pariwisata Indonesia saat ini menunjukkan perkembangan yang semakin meningkat. Pemerintah menetapkan bahwa pariwisata sebagai sarana pembangunan dapat menjadi penghasil devisa nomor dua setelah minyak dan gas bumi. Salah satu tempat pariwisata yang cukup terkenal di Indonesia adalah Dunia Fantasi. Dunia Fantasi merupakan pusat hiburan outdoor terbesar di Indonesia yang memanjakan para pengunjung dengan Fantasi Keliling Dunia. Dunia Fantasi menyediakan wahana permainan berteknologi tinggi yang terbagi dalam 8 kawasan, yaitu Indonesia, Jakarta, Asia, Eropa, Amerika, Yunani, Hikayat dan Balada Kera.

Sebagai pusat hiburan outdoor terbesar di Indonesia, Dunia Fantasi juga perlu memberikan pelayanan terbaik bagi pengunjungnya. Bahkan dewasa ini ada pepatah yang menyebut "pelanggan adalah raja” yang harus dengan segera dipenuhi keinginannya, seperti dilayani secara cepat, tepat dan akurat. Pengunjung dibuat senyaman mungkin dengan keramahtamahan dan sopan santun para karyawan. Pengunjung juga dibuat merasa nyaman dengan fasilitas yang disediakan oleh tempat wisata.

Dunia Fantasi sebagai pusat hiburan terbesar di Indonesia juga sering ramai dengan pengunjung terutama di saat akhir pekan, liburan sekolah ataupun liburan Nasional. Ramainya pengunjung Dunia Fantasi seringkali menyebabkan pelayanan yang diberikan menjadi kurang maksimal sehingga dapat menyebabkan ketidakpuasan pengunjung Dunia Fantasi. Beberapa faktor yang dapat dilihat seperti kebersihan tempat bermain, lahan parkir yang memadai, serta permainan yang menarik bagi pengunjung sangat mempengaruhi kepuasan pengunjung. Pada saat ini sebagai pusat hiburan outdoor terbesar di Indonesia belum ada alat ukur kepuasan pelanggan di tahun 2014. Maka dari itu, penelitian ini dibuat untuk mengukur sejauh mana kualitas pelayanan yang mampu diberikan Dunia Fantasi diukur dari dimensi pariwisata yang ada serta usulan apa saja yang bisa diberikan untuk perbaikan kualitas ke depannya. 


\section{TINJAUAN PUSTAKA}

\section{Kualitas Pelayanan}

Kualitas merupakan suatu kondisi dinamis yang berpengaruh dengan produk, jasa, manusia, proses dan lingkungan yang memenuhi atau melebihi harapan [1]. Sehingga definisi kualitas pelayanan dapat diartikan sebagai upaya pemenuhan kebutuhan dan keinginan konsumen serta ketepatan penyampaiannya dalam mengimbangi harapan konsumen [2].

Kualitas pelayanan (service quality) dapat diketahui dengan cara membandingkan persepsi para konsumen atas pelayanan yang nyata-nyata mereka terima/peroleh dengan pelayanan yang sesungguhnya mereka harapkan/inginkan terhadap atribut-atribut pelayanan suatu perusahaan. Jika jasa yang diterima atau dirasakan (perceived service) sesuai dengan yang diharapkan, maka kualitas pelayanan dipersepsikan baik dan memuaskan, jika jasa yang diterima melampaui harapan konsumen, maka kualitas pelayanan dipersepsikan sangat baik dan berkualitas. Sebaliknya jika jasa yang diterima lebih rendah daripada yang diharapkan, maka kualitas pelayanan dipersepsikan buruk.

\section{Konsep SERVQUAL}

Servqual merupakan pemilihan skala yang ringkas namun memiliki tingkat dan kebenaran yang cukup tinggi yang dapat digunakan manajemen perusahaan agar lebih mengerti bagaimana persepsi konsumen dan harapan konsumen akan pelayanan yang diberikan. Dalam situasi ini, manajemen perusahaan bersikap seakan-akan sebagai pihak pembeli dan pengkonsumsi jasa (bukan penyedia jasa). Telah dicapai konsensus bahwa harapan pelanggan (customer expctation) memainkan peran yang penting sebagai standar perbandingan dalam mengevaluasi kualitas maupun kepuasan pelanggan. Konsep servqual digunakan untuk menghitung gap antara persepsi konsensus terhadap jasa dan nilai ekspektasi atau harapan. Berikut adalah persamaannya:

$\mathrm{Q}=\mathrm{P}-\mathrm{E}$
Keterangan :

Q : Kualitas pelayanan (Quality of Service)

$\mathrm{P} \quad$ : Perceived service atau persepsi akan layanan

E : Expected service atau harapan akan layanan.

\section{METODOLOGI PENELITIAN}

Flowchart metodologi penelitian dapat dilihat pada gambar berikut:

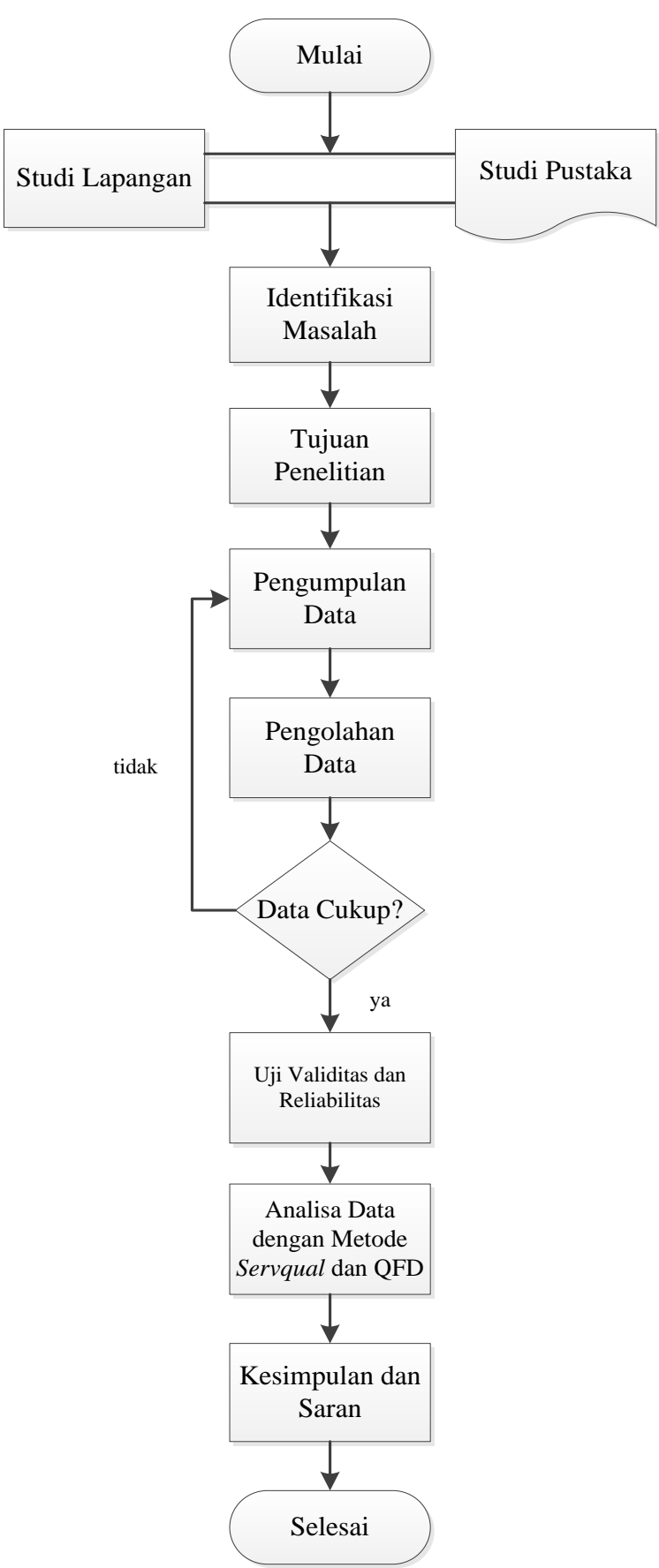

Gambar 1. Flowchart Metodologi Penelitian 
Penelitian dilakukan dengan mengumpulkan data dan informasi secara langsung dari pengunjung Dunia Fantasi. Jumlah rata-rata pengunjung Dunia Fantasi pada hari Sabtu, Minggu atau hari libur sebanyak 10.422 pengunjung. Pembagian kuesioner awal sebanyak 30 kuesioner dijadikan sebagai sampel yang diuji validitas dan reliabilitasnya. Apabila butir-butir kuesioner valid dan reliabel maka kuesioner akan dibagikan sesuai dengan jumlah responden yang dibutuhkan dalam penelitian untuk dihitung dengan model servqual.

Berdasarkan hasil dari perhitungan dengan rumus Cochran untuk mengetahui jumlah sampel minimum untuk kuesioner yang harus disebar adalah sebanyak 192. Dalam penelitian ini dibagikan kuesioner sebanyak 200 responden. Selanjutnya dilakukan uji validitas dan reliabilitas dari kuesioner yang telah diisi oleh responden. Setelah mengetahui apakan tiap butir kuesioner tersebut valid dan reliable maka dilakukan analisis gap dan analisis importanceperformance diikuti dengan pembuatan house of quality berbasiskan konsep metode quality fuction deployment.

Dimensi yang digunakan untuk mengidentifikasi variabel adalah dimensi pariwisata yang diperoleh dari variabel supply [3] ditambah dengan dimensi assurance [4], yaitu:

1) Atraksi Wisata (Attractions)

2) Fasilitas (Facilities)

3) Transportasi dan infrastruktur (Transportation and infrastructur)

4) Pelayanan (Hospitality)

5) Informasi dan promosi (Information and promotion)

6) Harga (Price)

7) Jaminan Keamanan (Security Assurance)

Variabel-variabel penelitian merupakan atribut atau item spesifik dari setiap dimensi kualitas jasa. Untuk mengetahui variabelvariabel yang terkait dengan penelitian kualitas jasa di taman hiburan Dunia Fantasi maka sebelumnya dilakukan studi pusataka dan studi pendahuluan di taman hiburan Dunia Fantasi. Hasil studi pustaka dan studi pendahuluan digunakan untuk membantu di dalam mengidentifikasikan variabel-variabel yang terkait dengan penelitian. Variabel-Variabel yang digunakan dalam kuesioner adalah:

1) Dimensi Atraksi Wisata

Tabel 1. Variabel Penelitian Dimensi Atraksi Wisata

\begin{tabular}{cl}
\hline Ket. & \multicolumn{1}{c}{ Variabel Penelitian } \\
\hline X1 & Jumlah Permainan yang mencukupi \\
X2 & Keberagaman jenis dan variasi atraksi permainan \\
X3 & Atraksi permainan yang ada tidak monoton \\
X4 & Ketersediaan atraksi permainan untuk segala \\
& jenis umur \\
X5 & Kebersihan, kelengkapan dan penampilan \\
& fasilitas permainan yang menarik \\
X6 & Ketersediaan atraksi permainan yang lebih \\
& menantang \\
X7 & $\begin{array}{l}\text { Peralatan Atraksi permainan dan hiburan yang } \\
\text { modern }\end{array}$ \\
X8 & Waktu permainan yang mencukupi \\
X9 & Fasilitas atraksi permainan yang terawat \\
X10 & Atraksi permainan memperhatikan kenyamanan \\
& dan keselamatan \\
X11 & Hiburan - hiburan yang diadakan menarik dan \\
& inovatif \\
\hline
\end{tabular}

\section{2) Dimensi Fasilitas}

Tabel 2. Variabel Penelitian Dimensi Fasilitas

\begin{tabular}{cl}
\hline Ket. & \multicolumn{1}{c}{ Variabel Penelitian } \\
\hline X1 & Fasilitas tempat hiburan yang bersih dan nyaman \\
X2 & $\begin{array}{l}\text { Ketersediaan fasilitas audio selama menikmati } \\
\text { permainan }\end{array}$ \\
X3 & $\begin{array}{l}\text { Jumlah tempat istirahat, restoran (kantin), toilet } \\
\text { dan tempat sampah }\end{array}$ \\
X4 & Ketersediaan dan kelengkapan fasilitas P3K \\
X5 & Fasilitas tempat parkir yang bersih dan \\
& memadai (tertata dengan baik dan beratap) \\
\hline
\end{tabular}

3) Dimensi Transportasi dan Infrastruktur

Tabel 3. Variabel Penelitian Dimensi Transportasi dan Infrastruktur

\begin{tabular}{cl}
\hline Ket. & \multicolumn{1}{c}{ Variabel Penelitian } \\
\hline X1 & Taman rekreasi bersih dan tertata dengan baik \\
X2 & $\begin{array}{l}\text { Ketersediaan Sarana transportasi yang mudah } \\
\text { dan murah }\end{array}$ \\
X3 & Kemudahan dalam menuju lokasi \\
X4 & Ketersediaan dan kemudahan sarana \\
& komunikasi \\
X5 & Kemudahan dalam menghubungi dan menemui \\
& $\begin{array}{l}\text { petugas loket tiket dan } \\
\text { operator permainan }\end{array}$ \\
X6 & $\begin{array}{l}\text { Kemudahan dalam menghubungi dan menemui } \\
\text { petugas restoran dan toilet }\end{array}$ \\
X7 & Kemudahan dalam menghubungi dan menemui \\
& petugas parkir dan keamanan \\
\hline
\end{tabular}


4) Dimensi Pelayanan

Tabel 4. Variabel Penelitian Dimensi Pelayanan

\begin{tabular}{|c|c|}
\hline Ket. & Variabel Penelitian \\
\hline $\mathrm{X} 1$ & $\begin{array}{l}\text { Tanggung jawab yang dimiliki petugas loket } \\
\text { tiket dan operator permainan }\end{array}$ \\
\hline $\mathrm{X} 2$ & $\begin{array}{l}\text { Tanggung jawab yang dimiliki petugas } \\
\text { restoran dan toilet }\end{array}$ \\
\hline X3 & $\begin{array}{l}\text { Tanggung jawab yang dimiliki petugas parkir } \\
\text { dan keamanan }\end{array}$ \\
\hline $\mathrm{X} 4$ & $\begin{array}{l}\text { Tanggung jawab pihak manajemen (pengelola) } \\
\text { dalam menangani keluhan dalam pelayanan } \\
\text { dan menangani kondisi darurat (kecelakaan) }\end{array}$ \\
\hline $\mathrm{X} 5$ & $\begin{array}{l}\text { Kesopanan dan keramahan petugas loket tiket } \\
\text { dan operator permainan }\end{array}$ \\
\hline X6 & $\begin{array}{l}\text { Kesopanan dan keramahan petugas restoran } \\
\text { dan toilet }\end{array}$ \\
\hline $\mathrm{X} 7$ & $\begin{array}{l}\text { Kesopanan dan keramahan petugas parkir dan } \\
\text { keamanan }\end{array}$ \\
\hline $\mathrm{X} 8$ & $\begin{array}{l}\text { Kerapian dan penampilan yang menarik } \\
\text { petugas loket tiket dan operator permainan }\end{array}$ \\
\hline X9 & $\begin{array}{l}\text { Kerapian dan penampilan yang menarik } \\
\text { petugas restoran dan toilet }\end{array}$ \\
\hline $\mathrm{X} 10$ & $\begin{array}{l}\text { Kerapian dan penampilan yang menarik } \\
\text { petugas parkir dan keamanan }\end{array}$ \\
\hline X11 & $\begin{array}{l}\text { Kesigapan petugas petugas loket tiket dan } \\
\text { operator permainan dalam memberikan } \\
\text { pelayanan }\end{array}$ \\
\hline $\mathrm{X} 12$ & $\begin{array}{l}\text { Kesigapan petugas restoran dan toilet dalam } \\
\text { memberikan pelayanan }\end{array}$ \\
\hline $\mathrm{X} 13$ & $\begin{array}{l}\text { Kesigapan petugas petugas parkir dan } \\
\text { keamanan dalam memberikan pelayanan }\end{array}$ \\
\hline X14 & $\begin{array}{l}\text { Kompetensi yang dimiliki petugas loket tiket } \\
\text { dan operator permainan dalam menjalankan } \\
\text { tugas pelayanan }\end{array}$ \\
\hline X15 & $\begin{array}{l}\text { Kompetensi yang dimiliki petugas restoran dan } \\
\text { toilet dalam menjalankan tugas pelayanannya }\end{array}$ \\
\hline X16 & $\begin{array}{l}\text { Kompetensi yang dimiliki petugas parkir dan } \\
\text { keamanan dalam menjalankan tugas } \\
\text { pelayanannya }\end{array}$ \\
\hline $\mathrm{X} 17$ & $\begin{array}{l}\text { Komunikatif dan keaktifan operator dalam } \\
\text { mengarahkan pengunjung (didukung sound } \\
\text { audio) }\end{array}$ \\
\hline
\end{tabular}

5) Dimensi Informasi dan Promosi

Tabel 5. Variabel Penelitian Dimensi Informasi dan Promosi

\begin{tabular}{cl}
\hline Ket. & \multicolumn{1}{c}{ Variabel Penelitian } \\
\hline X1 & $\begin{array}{l}\text { Papan petunjuk yang jelas dan dapat } \\
\text { menginformasikan letak fasilitas permainan } \\
\text { dan pelayanan }\end{array}$ \\
X2 & $\begin{array}{l}\text { Ketersediaan information center untuk } \\
\text { pengunjung }\end{array}$ \\
X3 & $\begin{array}{l}\text { Kemudahan dalam memperoleh informasi } \\
\text { tentang atraksi permainan dan hiburan yang }\end{array}$ \\
& ada melalui media cetak dan elektronik \\
X4 & Kegiatan promosi yang di lakukan menarik \\
\hline
\end{tabular}

\section{6) Dimensi Harga}

Tabel 6. Variabel Penelitian Dimensi Harga

\begin{tabular}{cl}
\hline Ket. & \multicolumn{1}{c}{ Variabel Penelitian } \\
\hline X1 & Harga tiket masuk terjangkau dan murah \\
X2 & $\begin{array}{l}\text { Harga makanan dan minuman terjangkau dan } \\
\text { murah }\end{array}$ \\
X3 & $\begin{array}{l}\text { Program paket harga permainan terjangkau } \\
\text { dan murah }\end{array}$ \\
X4 & Harga souvenir terjangkau dan murah \\
\hline
\end{tabular}

7) Dimensi Jaminan Keamanan

Tabel 7. Variabel Penelitian Dimensi Jaminan Keamanan

\begin{tabular}{cl}
\hline Ket. & \multicolumn{1}{c}{ Variabel Penelitian } \\
\hline X1 & $\begin{array}{l}\text { Terjaminnya keamanan dan keselamatan } \\
\text { pengunjung serta barang bawaan di taman } \\
\text { rekreasi dan hiburan }\end{array}$ \\
X2 & $\begin{array}{l}\text { Terjaminnya keselamatan dan keamanan } \\
\text { pengunjung dalam menikmati fasilitas }\end{array}$ \\
& permainan yang ada \\
X3 & $\begin{array}{l}\text { Terjaminnya keamanan kendaraan } \\
\text { pengunjung di tempat parkir }\end{array}$ \\
\hline
\end{tabular}

\section{HASIL DAN PEMBAHASAN \\ Penentuan Jumlah Sampel}

Penentuan jumlah sampel minimal dengan menggunakan rumus Cochran, yaitu:

$n=\frac{N P Q}{(N-1) D+P Q}$

Keterangan :

$\mathrm{n} \quad$ : Jumlah minimal sampel

$\mathrm{N}$ : Jumlah rata-rata pengunjung Dunia Fantasi

$\mathrm{P}$ : Proporsi responden memilih pertanyaan tertentu $(0,5)$

Q : (1-P) Proporsi responden memilih pertanyaan tertentu $(0,5)$

$\mathrm{D}$ : Tingkat ketelitian $=\frac{B^{2}}{Z_{\alpha / 2}}$

B : Tingkat kesalahan $0,05\left(Z_{\alpha / 2}=1,96\right)$

\section{Uji Validitas dan Reliabilitas}

Uji Validitas dan Reliabilitas dilakukan dengan menggunakan program SPSS 16. Metode yang digunakan dalam uji validitas ini adalah validitas internal, dengan menggunakan korelasi pearson. Uji Validitas dilakukan untuk mengetahui tingkat kevalidan dari instrumen (kuesioner) yang digunakan dalam 
pengumpulan data yang diperoleh dengan cara mengkorelasi setiap skor variabel jawaban responden dengan total skor masing-masing variabel, kemudian hasil korelasi dibandingkan dengan nilai kritis pada taraf signifikan 0,05 dan 0,01. Interpretasi yang digunakan dengan menggunakan tanda flag (*) yang menunjukkan bahwa indikator tersebut signifikan pada taraf $5 \%$ dan tanda flag $(* *)$ yang menunjukkan bahwa indikator tersebut valid pada taraf $1 \%$. Pada uji reliabilitas menggunakan koefisien reliabilitas Cronbach Alpha.

Hasil Uji Validitas berdasarkan program SPSS 16 menunjukkan hasil valid pada tiap butirnya dan hasil uji reliabilitas menunjukkan hasil nilai Cronbach Alpha lebih besar dari 0,7 sehingga dinyatakan reliabel.

\section{Perhitungan GAP Hasil Kuesioner dengan Metode SERVQUAL}

Hasil kuesioner SERVQUAL dihitung dengan mengalikan hasil kuesioner persepsi dan ekspektasi dengan bobot yang telah ditentukan. Bobot 5 untuk nilai variabel sangat puas, bobot 4 untuk variabel puas, bobot 3 untuk variabel cukup, bobot 2 untuk variabel tidak puas dan bobot 1 untuk variabel sangat tidak puas. Setelah dikalikan dengan nilai bobot, kemudian dicari nilai rata-rata untuk persepsi dan ekspektasi, kemudian hasil dari persepsi dikurang dengan ekspektasi untuk mendapatkan nilai GAP.

Nilai rata-rata persepsi, ekspektasi serta GAP dapat dilihat pada tabel berikut:

1) Dimensi Atraksi dan Hiburan

Tabel 8. GAP Dimensi Atraksi dan Hiburan

\begin{tabular}{crrr}
\hline Variabel & Persepsi & Ekspektasi & \multicolumn{1}{c}{ GAP } \\
\hline X1 & 3,47 & 4,53 & $-1,06$ \\
X2 & 3,64 & 4,62 & $-0,98$ \\
X3 & 3,29 & 4,37 & $-1,08$ \\
X4 & 3,22 & 4,66 & $-1,44$ \\
X5 & 3,62 & 4,57 & $-0,95$ \\
X6 & 3,6 & 4,65 & $-1,05$ \\
X7 & 3,43 & 4,56 & $-1,13$ \\
X8 & 2,79 & 4,78 & $-1,99$ \\
X9 & 3,19 & 4,64 & $-1,45$ \\
X10 & 3,45 & 4,72 & $-1,27$ \\
X11 & 3,14 & 4,63 & $-1,49$ \\
\hline
\end{tabular}

Nilai GAP rata-rata $=-13,89 / 11=-1,2627$
2) Dimensi Fasilitas

Tabel 9. GAP Dimensi Fasilitas

\begin{tabular}{ccrr}
\hline Variabel & Persepsi & Ekspektasi & \multicolumn{1}{c}{ GAP } \\
\hline X1 & 2,82 & 4,56 & $-1,74$ \\
X2 & 3,07 & 4,33 & $-1,26$ \\
X3 & 3,25 & 4,56 & $-1,31$ \\
X4 & 2,68 & 4,47 & $-1,79$ \\
X5 & 2,27 & 4,71 & $-2,44$ \\
\hline
\end{tabular}

Nilai GAP rata-rata $=-8,54 / 5=-1,708$

3) Dimensi Transportasi Dan Infrastruktur

Tabel 10. GAP Dimensi Transportasi dan Infrastruktur

\begin{tabular}{crrr}
\hline Variabel & Persepsi & Ekspektasi & \multicolumn{1}{l}{ GAP } \\
\hline X1 & 2,71 & 4,79 & $-2,08$ \\
X2 & 3,43 & 4,62 & $-1,19$ \\
X3 & 3,19 & 4,61 & $-1,42$ \\
X4 & 3,16 & 4,56 & $-1,4$ \\
X5 & 3,31 & 4,53 & $-1,22$ \\
X6 & 3,59 & 4,62 & $-1,03$ \\
X7 & 3,02 & 4,66 & $-1,64$ \\
\hline
\end{tabular}

Nilai GAP rata-rata $=-9,98 / 7=-1,4257$

4) Dimensi Pelayanan

Tabel 11. GAP Dimensi Pelayanan

\begin{tabular}{crrr}
\hline Variabel & Persepsi & Ekspektasi & \multicolumn{1}{c}{ GAP } \\
\hline X1 & 3,34 & 4,58 & $-1,24$ \\
X2 & 3,16 & 4,63 & $-1,47$ \\
X3 & 3,16 & 4,56 & $-1,4$ \\
X4 & 3,18 & 4,65 & $-1,47$ \\
X5 & 3,49 & 4,67 & $-1,18$ \\
X6 & 3,28 & 4,54 & $-1,26$ \\
X7 & 3,16 & 4,64 & $-1,48$ \\
X8 & 3,31 & 4,56 & $-1,25$ \\
X9 & 3,22 & 4,56 & $-1,34$ \\
X10 & 3,18 & 4,67 & $-1,49$ \\
X11 & 3,27 & 4,76 & $-1,49$ \\
X12 & 3,27 & 4,66 & $-1,39$ \\
X13 & 3,31 & 4,75 & $-1,44$ \\
X14 & 3,13 & 4,75 & $-1,62$ \\
X15 & 3,21 & 4,68 & $-1,47$ \\
X16 & 3,19 & 4,58 & $-1,39$ \\
X17 & 3,03 & 4,57 & $-1,54$ \\
\hline Nilai GAP rata-rata $=-23,29 / 17=-1,4071$
\end{tabular}

5) Dimensi Informasi dan Promosi

Tabel 12. GAP Dimensi Informasi dan Promosi

\begin{tabular}{crrr}
\hline Variabel & Persepsi & Ekspektasi & \multicolumn{1}{c}{ GAP } \\
\hline X1 & 3,4 & 4,76 & $-1,36$ \\
X2 & 3,34 & 4,67 & $-1,33$ \\
X3 & 3,3 & 4,73 & $-1,43$ \\
X4 & 3,49 & 4,57 & $-1,08$ \\
\hline
\end{tabular}


Nilai GAP rata-rata $=-5,2 / 4=-1,3$

6) Dimensi Harga

Tabel 13. GAP Dimensi Harga

\begin{tabular}{crrr}
\hline Variabel & Persepsi & Ekspektasi & \multicolumn{1}{c}{ GAP } \\
\hline X1 & 2,44 & 4,89 & $-2,45$ \\
X2 & 2,29 & 4,78 & $-2,49$ \\
X3 & 2,53 & 4,8 & $-2,27$ \\
X4 & 2,32 & 4,67 & $-2,35$ \\
\hline
\end{tabular}

Nilai GAP rata-rata $=-9,56 / 4=-2,39$

7) Dimensi Jaminan Keamanan

Tabel 14. GAP Dimensi Jaminan Keamanan

\begin{tabular}{crrr}
\hline Variabel & Persepsi & Ekspektasi & \multicolumn{1}{c}{ GAP } \\
\hline X1 & 2,83 & 4,77 & $-1,94$ \\
X2 & 2,85 & 4,92 & $-2,07$ \\
X3 & 2,83 & 4,88 & $-2,05$ \\
\hline
\end{tabular}

Nilai GAP rata-rata $=-6,06 / 3=-2,02$

Berdasarkan hasil perhitungan kuesioner, seluruh atribut yang diteliti bernilai negatif yang artinya atribut tersebut masih belum memenuhi kepuasan pengunjung Dunia Fantasi, maka dari itu untuk seluruh atribut masih perlu ditingkatkan lagi untuk dapat memenuhi kepuasan pengunjung.

\section{Importance-Performance Analysis}

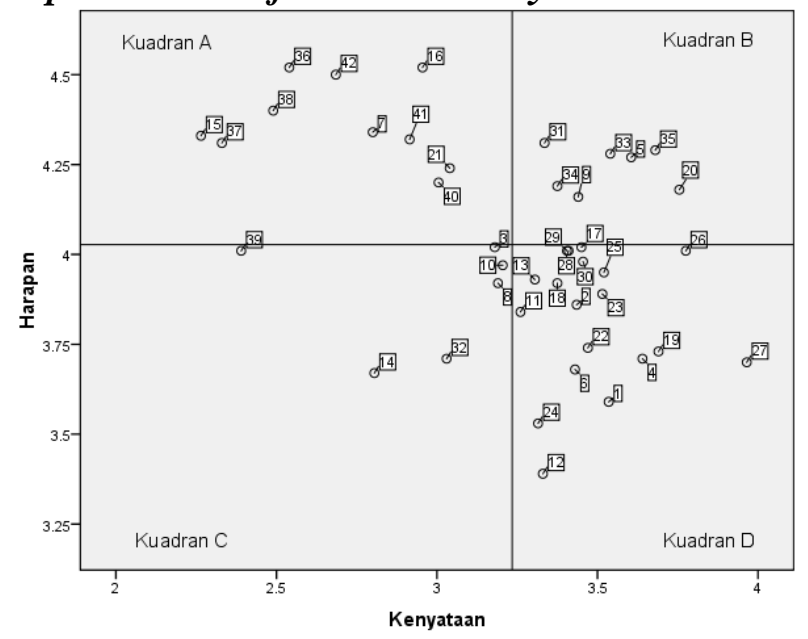

Gambar 2. Grafik Importance-Performance Analysis

Berdasarkan grafik ImportancePerformance Analysis kuadran A menunjukkan nilai variabel yang dianggap penting bagi pengunjung tetapi masih kurang memuaskan dalam pelayanan sehingga variabel pada kuadran A akan dilanjutkan untuk diberikan solusi dengan metode QFD.

\section{House of Quality}

Berdasarkan hasil perhitungan dengan metode QFD, maka solusi yang diberikan untuk perbaikan variabel pada kuadran A dapat dilihat pada rumah kualitas Gambar 3.

\section{KESIMPULAN}

Hasil nilai rata-rata GAP dari tiap dimensi pariwisata adalah untuk dimensi atraksi dan hiburan bernilai -1,2627, dimensi Fasilitas bernilai - 1,708, dimensi Transportasi dan Infrastruktur bernilai -1,4257, dimensi pelayanan bernilai $-1,407$, dimensi Informasi dan Promosi bernilai -1,3, dimensi Harga bernilai -2,39, dimensi jaminan keamanan bernilai -2,02. Kualitas layanan di Dunia Fantasi yang ada saat ini masih kurang memuaskan pengunjung karena nilai kepuasan lebih kecil dari nilai yang diharapkan konsumen. Hal ini terbukti dari nilai gap seluruhnya bernilai negatif. Kebutuhan teknis yang diinginkan pengunjung terdapat 10 atribut, yaitu waktu permainan yang mencukupi, fasilitas tempat parkir memadai, taman rekreasi bersih dan tertata dengan baik, kemudahan dalam menghubungi dan menemui petugas keamanan, harga tiket masuk arena wisata terjangkau dan murah, harga makanan dan minuman terjangkau dan murah, program paket harga permainan dunia fantasi terjangkau dan murah, terjaminnya keamanan dan keselamatan pengunjung serta barang bawaan di taman rekreasi dan hiburan, terjaminnya keselamatan dan keamanan pengunjung dalam menikmati fasilitas permainan yang ada dan terjaminnya keamanan kendaraan pengunjung di tempat parkir. Usulan rancangan pelayanan berdasarkan tingkat prioritas adalah penambahan jumlah petugas keamanan, penggabungan promo makanan dan paket permainan dengan harga khusus, penambahan petugas keamanan di tempat parkir, penambahan jumlah dan waktu operasional petugas kebersihan, pengadaan harga khusus untuk tiket masuk arena wisata pada hari raya tertentu, pengadaan promo harga paket permainan murah, penambahan waktu 
permainan dan penambahan intensitas pengecekan mesin dan fitur pengamanan pada permainan. Usulan perbaikan lebih detail dapat dilihat pada gambar rumah kualitas yang telah dibuat.

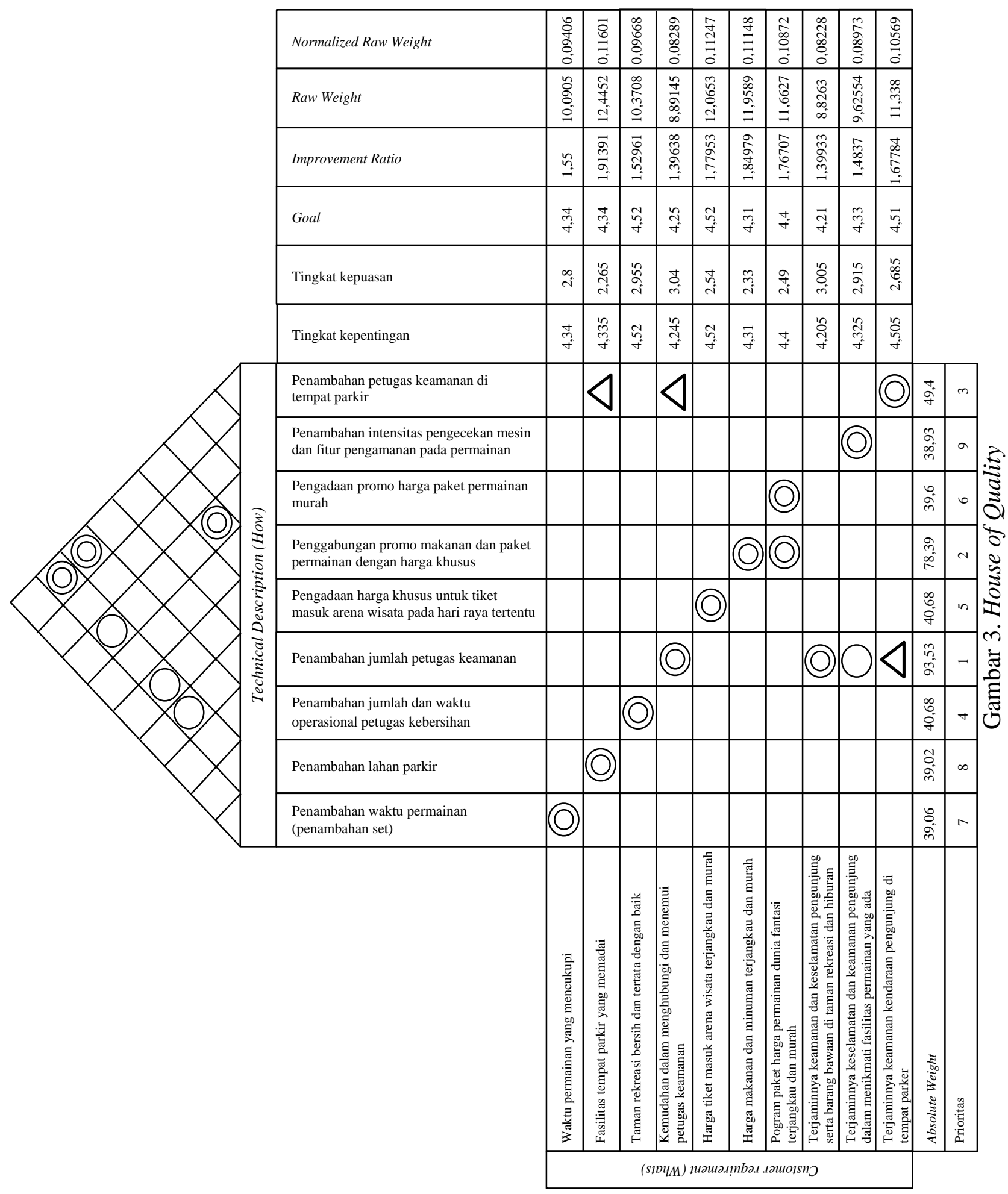




\section{DAFTAR PUSTAKA}

[1] Tjiptono, F, \& Chandra A., 2002, Service Quality Satisfaction, Andi offset, Yogyakarta

[2] Tjiptono, F, \& Diana, A., 2003, Total Quality Management, Edisi Revisi, ANDY, Yogyakarta.

[3] Spillane, James J., 1994, Ekonomi Pariwisata, Sejarah dan Prospeknya, Yogyakarta, Kanisius.

[4] Parasuraman, Leonard L., Berry, 1990, Delivering Quality, The Free Press New York.

[5] Syaiful, Anwar Agus, 2013, Perbaikan Kualitas Layanan Jasa dengan Model Servqual Dimensi Kepariwisataan dan
Metode Quality Function Deployment (Studi Kasus di PT. X, Tempat Wisata Wahana Permainan), Program Studi Teknik Industri Fakultas Teknik Universitas Diponegoro, Semarang.

[6] Wulandari, Sri Hariani Eko, 2011, Strategi Peningkatan Kualitas Layanan Pendidikan Menggunakan Integrasi Metode Fuzzy Servqual dan QFD (Studi Kasus: Program Studi S1 Sistem Informasi STIKOM Surabaya), Program Magister Manajemen Teknologi Industri Institut Teknologi Sepuluh November, Surabaya. 